\title{
Uncertainty and Private Investment Decision in Malaysia
}

\author{
Lay Lian Chuah ${ }^{1}$, Wai Ching Poon ${ }^{2} \&$ Balachandher Krishnan Guru ${ }^{2}$ \\ ${ }^{1}$ Economics Department, Bank Negara Malaysia, Malaysia \\ ${ }^{2}$ School of Business, Monash University Malaysia, Malaysia \\ Correspondence: School of Business, Monash University Malaysia, Jalan Lagoon Selatan, 46150 Bandar Sunway, \\ Selangor, Malaysia. Tel: 603-5514-4908. Fax: 603-5514-6192. E-mail: poon.wai.ching@monash.edu
}

Received: July 30, 2018

Accepted: August 8, 2018

Online Published: August 14, 2018

doi:10.5539/mas.v12n9p71

URL: https://doi.org/10.5539/mas.v12n9p71

\begin{abstract}
This study examines the effects of uncertainty on irreversible aggregate investment using data from 1971-2010. Results provide evidence to support the argument that macroeconomic uncertainties are important in the forwardlooking investment decision-making process. This study concludes that the demand and lagged demand uncertainties have a relatively stronger effect on investments compared with other macro uncertainties. The structure of the economy, the depth of the financial system, and the promotion of trade openness reduce the negative impact of uncertainties on investment. The study also finds the elasticity of the user cost of capital to be less than unity, indicating limited scope for governments to influence investment through tax incentives.
\end{abstract}

Keywords: Uncertainty, irreversible, investment, $\mathrm{ARCH} / \mathrm{GARCH}$, Malaysia

\section{Introduction}

Demand uncertainty tends to reduce investment (Pindyck, 1988). Firms naturally spend less on irreversible investments than they would on reversible ventures, given the environment of demand uncertainty. Irreversibility of capital is characterised by the sunk cost of investment as de-installation of capital may be costly and the resale value of the second-hand capital is likely to be limited. World Bank (2011) has suggested that Malaysia's private investment has been too low, especially in view of its aspiration to become a dynamically efficient innovation-led economy. Private investments in Malaysia have become less responsive to the improvements in the investment climate, and the negative sentiments continued to linger post-Asian Financial Crisis (AFC). The ratio of private investments to GDP in Malaysia reached a peak of $31 \%$ in the pre-AFC period, but plunged to an average of less than 13\% during 2000-2011 in the post-AFC period. However, it remains unclear to explain the underlying causes of the prolonged sluggishness in private investments post-AFC, despite the government's encouragement to revive private investments. Theoretical debates in the literature have not been able to provide a conclusive answer. We argue that the sluggish investment performance in the post-AFC is not adequately explained by the conventional determinants of investment behaviour. Thus, this study bridges the gap beyond conventional investment theoretical constraints and links the forces of uncertainty with investment behaviour. The contribution of this study is that not only we focus on the role of uncertainty, but also examine the varying impact of different macro uncertainties on irreversible investments, with a view to explain the Malaysian phenomenon of sluggish private investments during the post-AFC period.

While there is body of literature that found a negative relationship between uncertainties and investment growth (Carruth et al., 2000; Ramey and Ramey, 1995), the magnitude and the significance of the influence remain inconclusive. Some studies found a weak negative relationship between uncertainty and investment for countries with less well-developed financial systems (e.g., Servén, 2003), while others found no evidence of a weaker negative link between uncertainty and economic growth when financial depth was included in the model (e.g., Hnatkovska and Loayza, 2005). Domestic financial sector development is instrumental in fostering growth, and pooling of resources during economic distress. Underdeveloped financial markets prevent an efficient allocation of resources, resulting in misallocation of resources during periods of economic shocks. Increasing the depth of the financial sector enhances long-term economic growth through more efficient allocation of funds and increasing innovation in the economy (Ghura and Goodwin, 2000; Servén, 2003; Rajan and Zingales, 1998; Levine and Zervos, 1998). Of significance is that with greater financial depth, we have more avenues to manage risks, minimise the impact of macro uncertainty on private investment, enhance capital formation and foster economic 
growth.

Adopting the neoclassical framework as the foundation for the empirical model, this study builds on existing work on irreversible decisions to answer "Does the effect of uncertainty in determining the behaviour of slow recovery in the Malaysia's private investments significant?" We also compare the significance of exogenous uncertainty with endogenous uncertainty. The comparison is essential to comprehend the behaviour of investment.

Our main findings show that uncertainty has an adverse effect on investment decisions due to the irreversible investment expenditure. The uncertainties of demand and lagged demand weaken the response of investment. Furthermore, the structure of the economy, the depth of the financial system, and the promotion of trade openness lessen the negative impact of uncertainty on investment since a greater financial sector depth allows higher risk diversification; while the openness of an economy promotes competition.

The contributions of this study to the investment-uncertainty nexus are three-fold. First, this study examines the impact of the different sources of uncertainties to assess a broader assessment of the role of uncertainties on private investment. The varying impact of uncertainty (such as price, exchange rate and interest rate uncertainties) is examined separately to develop policies that are more focused to target specific areas of vulnerability (Servén, 1998). Second, from a spectrum of exogenous and endogenous uncertainties, it fills the gap in extant literature which has been left by the paucity of research on the relative importance of exogenous (e.g. a change in world interest rates and a change in price) and endogenous uncertainties (e.g. perceived weakness in banking regulations and policies) on aggregated private investments. We assess whether these uncertainties have larger impact for a small and open economy in Malaysia. If endogenous demand uncertainty is found to be significant, it follows that the design of public policy should seek to reduce the perception of risk and promote macroeconomic stability; but if exogenous uncertainty (e.g. oil prices or real effective exchange rate (REER) shocks) are found to be significant, policy maker should seek to accommodate external uncertainties by diversifying the economic base or deepening the financial sector to facilitate the economy's ability to absorb external shocks. Third, we investigate the role of economic structure, the depth of financial development, and the extent of openness to trade in alleviating the negative effects of uncertainty. The lesson learnt from the AFC experience was that prior conditions could potentially increase an economy's vulnerability to external shocks. The risky conditions contributing to the exchange rate uncertainty (e.g. perverse incentives and policies and a vulnerability and fragility in the financial sector) should have been identified through surveillance and proactive adjustment policies.

This paper consists of five sections. Sections 2 presents the literature review on the theoretical underpinnings in the investment-uncertainty nexus. Section 3 discusses the construction of the measuring of uncertainty in the specification model, estimation issues, aggregated data structure and the data sources. Section 4 presents a discussion on the empirical findings and robustness estimations. Finally, the paper concludes in Section 5.

\section{Literature Review}

Investment is derived from how capital stock moves towards the desired levels, after accounting for the consumption of capital or the depreciation rate of capital. The neoclassical theory postulates that firms want to maximise their investment value, given a set of initial conditions and capitalised rates of expected returns. The neoclassical model includes delivery lags, adjustment costs and capital is assumed to depreciate at a geometric rate. These assumptions give rise to three problems: (i) the firm is expected to reach the optimal capital, instantaneously; (ii) the static expectations of future prices of output and; (iii) ad hoc inclusion of delivery lags into the model. These shortcomings implicitly suggest that firms do not need to consider the future, and therefore multi-period optimisation of profits becomes essentially static (Chirinko, 1993).

Neoclassical investment theory emphasizes on the response of the demand for capital to the changes in relative price of capital. The conventional investment models do not consider the irreversible characteristics of investments which involve sunk costs that may be fully or partially unrecoverable. The main weakness in the conventional investment models is that they do not explicitly consider the role of uncertainties (Chirinko, 1993; Hartman, 1972; Caballero, 1991; Dixit and Pindyck, 1994). Using a modified neoclassical framework as a theoretical foundation for the aggregated investment model, the specifications of the model have been modified to take into account the implications of the interaction of uncertainty. This augmented model includes a lagged investment process; accelerator effect; financing constraints; and macroeconomic uncertainty.

While the findings of past studies provided some insights to better understand the role of uncertainty, they are predominantly focused on the investment behaviour of developed countries (e.g. Dixit and Pindyck, 1994; Huzinga, 1993; Byrne and Davis, 2005a, 2005b; Temple et al., 2001; Bernanke, 1983; Bloom et al., 2007), or other developing or less-developed countries (e.g. Jongwanich and Kohpaiboon, 2008; Fielding, 1997; Aizenman and Marion, 1999; TunWai and Wong, 1982; Servén, 2003; Aysan et al., 2009). Few studies focused on Malaysia, have 
either found uncertainty to be insignificant or have only considered a single source of uncertainty in the investment models (Note 1). Compared to Price (1995), Aysan et al., (2009), Temple et al., (2001) and Bloom et al. (2007), who found the impact of demand uncertainty on investment to be within the range of -0.01 to -0.08 , Ang (2010) examined the impact of GDP uncertainty on private investments in Malaysia, and found a much smaller negative impact of 0.002 to 0.003 percentage points reduction in private investment for a one percent increase in GDP uncertainty. The small negative but significant demand uncertainty coefficient may suggest that there are probably other sources of uncertainty which affect private investments.

While many common uncertainty variables have been identified as determinants of private investment, the similar variable showed mixed results with respect to its significance. For instance, Guimaraes and Unteroberdoerster (2006) found that real exchange rate (RER) uncertainty is statistically insignificant in influencing private investments. But Servén (2003) found the impact of RER uncertainty on private investment to be negative and significant for low-income countries, and insignificant for high-income countries. Apart from the income differences, Servén reported that countries with low capital-labour ratios tend to have a more significant response towards RER uncertainty compared to countries with high capital-labour ratios. The impact of RER uncertainty on investments could be due to the pass-through effects and the sensitivity of prices to exchange rate movements. The pass-through effects of RER uncertainty may lead to uncertainty in the user cost of capital, especially for high import content capital.

Past studies show uncertainty leads to a disproportionate response of investment. In the case of the impact of RER volatility on investment, Jongwanich and Kohpaiboon (2008) found that a one percent increase in RER uncertainty would lead to a fall of $0.02 \%$ in investments, and it takes between $6-10$ years for the economy to adjust to the investment imbalances. However, Ang (2010) estimated a shorter 2.5-year time frame for investment to return to its long-term equilibrium.

The extensive literature provides inconclusive results to the question whether uncertainty reduces investment. Many studies generally support the notion that uncertainty tend to have an adverse effect on irreversible investment. Aysan et al. (2009) found that interest rate uncertainty has a negative impact on investments in Middle East and North African countries, and Byrne and Davis (2005a) showed that a one standard deviation increases in the conditional volatility of long-term interest rates leads to a 2-4 percent fall in investment in the G-7 countries. However, trade openness may interact with RER uncertainty and change the overall impact of uncertainty on investments. Servén (2003) found a significant negative impact of RER uncertainty for countries with a low degree of trade openness, but insignificant in highly open economies. Campa and Goldberg's (1995) study on U.S. manufacturing industries found that the response of these industries towards an appreciation of the exchange rate increases in tandem with exposure to the external sector. They reported that a $10 \%$ appreciation had resulted in a decline of $0.5 \%$ in investments (1970-83 period), but the same quantum of appreciation only caused a $0.1 \%$ decline in investments (1984-86 period). The reason for the decline was that the U.S. had increased its reliance on imported inputs between the two periods.

The effects of openness could also be captured by the development of the financial system. An economy with a high degree of openness may benefit from cross-border exchanges of information which promotes greater competition and efficiency in the economy. These benefits may outweigh the negative effects of RER uncertainty. Greater financial deepening would encourage investments since it provides greater financial accessibility and facilitates greater risk diversification that gives positive effect on private investment (TunWai and Wong, 1982; Servén, 1998, 2003; Ghura and Goodwin, 2000; Aysan et al., 2009; Aizenman and Marion, 1999). Supporting this is Servén (2003) who found that the negative relationship between RER and investments is accentuated in countries with low financial depth. While the financial system plays an important role, its importance may be offset by the development of capital markets and cross-border financing (Note 2).

Easterly, Islam and Stiglitz (2000) argue that greater financial development is associated with lower growth volatility only up to a certain point, after which the financial sector could become a source of macroeconomic vulnerability because a rapidly growing financial sector competes with the rest of the economy for resources. Therefore, an underdeveloped financial sector can be detrimental to growth (Caballero, 2000), but rapid financial sector development may be associated with excessive risk taking practices which in turn undermines economic growth (Caballero, 2001).

Internal uncertainty (such as inflation and interest rate uncertainties) and external uncertainty (such as RER and to-t uncertainties) give different impacts. Using the GMM model, Servén (1998) found that internal uncertainties tend to have a greater impact as compared to external uncertainties (Note 3). He claimed that the size of the estimated coefficient of inflation uncertainty was about six times larger than the coefficient of RER uncertainty. 
Similarly, Jongwanich and Kohpaiboon (2008) showed that the impact of inflation uncertainty on private investments in Thailand is more important compared to RER uncertainty in the long run. Servén (1998) also found real interest rate uncertainty to have a significant negative impact on private investment.

Frequent price uncertainty would make investors extremely cautious despite the availability of investment incentives. Inflation uncertainty has a negative impact on GDP growth (Aizenman and Marion, 1999; Jongwanich and Kohpaiboon, 2008). Inflation uncertainty may affect investments directly through the cost of capital or indirectly through domestic demand that ultimately affect the demand for capital. Huizinga (1993) found that a one standard deviation increases in inflation uncertainty is estimated to have an immediate effect on investments in the range of +0.58 to -0.43 percent. A rise of output price uncertainty over three quarters is expected to reduce investments by 2.9 percent. While Huizinga's correlation analysis results statistically proves that price uncertainties are consistent with expectations, the results of his cross-sectional analysis appear to be contradictory. These studies indicate that there is scope for monetary policy to deal with inflation uncertainty because domestic prices also reflect the outcomes of monetary policy and investors' risk perception.

\section{Methodology}

\subsection{Model Specification}

The baseline model can be written as:

$$
i_{t}=f\left(i_{t-1}, X_{t}, \sigma_{t}\right)+u_{t}
$$

Where $i_{t}$ is the log of private investment, $X_{t}$ is a set of exogenous variables influencing private investments, $\sigma_{t}$ is a set of macroeconomic uncertainty variables and $u_{t}$ is a random disturbance. The set of $X_{t}$ variables captures the accelerator effect and user cost of capital. We use current and lagged levels of log real GDP to capture the investment accelerator effect, instead of the expected log real GDP since the actual values are more reflective of the actual underlying dynamics of economic activity. TunWai and Wong (1982), Servén (1998), Ghura and Goodwin (2000) and Guimaraes and Unteroberdoerster (2006) have used aggregated demand to capture the accelerator effect and all were found to have significant effects on private investment.

Neoclassical theory predicts that the user cost of capital should be the primary determinant of investment demand. This study uses two approaches to calculate the user cost of capital. The first approach is the relative price of capital as proxy for the user cost of capital. The relative price of capital measure is more simplistic as it does not take into consideration tax allowances and it uses the borrowing cost to represent the financial cost of capital. For the second approach, we measure the user cost of capital based on Hall and Jorgenson's (1967) formula as follows:

$$
u c_{t}=\left(r_{t}+\delta_{t}-\frac{\dot{p}_{t}}{p_{t}}\right) /\left(1-\tau_{t}\right)
$$

where $u c_{t}$ is the real user cost of capital at time $t, r_{t}$ is the real interest rate at time $t, \delta_{t}$ is the depreciation rate at time $t, \dot{p}_{t}$ is the change in the price of capital at time $t, p_{t}$ is the price of capital at time $t$ and $\tau_{t}$ is the corporate tax rate at time $t$. The depreciation rate is obtained from the consumption of capital by type of capital from the Department of Statistics Malaysia (DOSM). The depreciation is calculated by taking the ratio of the total consumption of capital to gross fixed capital during the year.

$$
\delta_{t}=\sum_{i}^{4} c k_{i, t} / \sum_{i}^{4} g k_{i, t}
$$

where $c k_{i, t}=$ consumption of $i$ type of fixed capital at time $t ; g k_{i, t}=$ gross capital stock (at current price) of $i$ at time $\mathrm{t} ; i=1$ represents structures, $i=2$ represents transport, $i=3$ represents machinery and equipment and $i=4$ represents others; and $\mathrm{t}=1970, \ldots, 2010$.

The model includes a proxy to represent the depth of the financial system which may be important in assuaging the impact of macro uncertainties as a more developed financial system enables firms to diversity their risks effectively. Financial deepening and the availability of financing are important as the degree to which banks can mediate funds into profitable projects can influence the cost of capital. The more developed financial systems tend to lower cost intermediation and thereby encourage private investment (TunWai and Wong, 1982; Ghura and Goodwin, 2000; Servén, 2003). The financial development variable is measured as the ratio of real loans to real GDP.

As Malaysia is an open economy, it tends to be more vulnerable to external shocks. Openness of the economy variable is included in the model to evaluate the benefits of being an open economy against the cost of external shocks' exposure. Openness is measured as the ratio of imports and exports to GDP. 
The effects of uncertainty in inflation and relative price of capital are expected to filter through the user cost of capital. Furthermore, uncertainty in domestic policy can also exhibit itself in the interest rate movements which, in turn may impact user cost of capital. In addition, domestic prices may, to some extent, reflect the impact of the country's monetary policy as well as the investors' risk perceptions (Note 4). Thus, uncertainty in inflation may affect investment directly through the cost of capital or indirectly through domestic demand which affects the demand for capital.

In an environment of uncertain demand, firms will opt for lower capacity if investment is irreversible than they would under conditions of reversibility of investment. The ex-post capacity level may actually be higher under irreversibility if demand is unexpectedly low. As such, Pindyck (1988) shows that increased volatility in demand, will generally lead to a reduction in investment.

Uncertainty measures of t-o-t and REER are important in determining investments as these uncertainties make profitability and the cost of new capital hard to predict (Note 5). The impact of uncertainty in REER on investment is in line with the predictions of theoretical models on pass-through effects and price sensitivity of exchange rate movements. In particular, the pass through effects of uncertainty in REER will result in uncertainty in the user cost of capital especially those with high import content.

One aspect of studying investments under conditions of uncertainty and irreversibility is in deciding an appropriate measure to represent uncertainty. In general, they can be divided into two broad categories, backward looking and forward looking. The backward-looking representations of uncertainty include most macro and firm-level financial indicators, while the forward-looking representations include risk premiums, share prices, sentiment indices and forecast information from surveys. Ferderer (1993) relates risk premium as measure of uncertainty by deriving a forward-looking uncertainty measure of risk premium on long-term bonds from the term structure of interest rates. $\mathrm{He}$ found that risk premium has a significant negative effect on aggregate investment, after controlling for the user cost of capital, which is consistent with the theory of investment irreversibility and uncertainty.

We are treating risk factors as a measure of uncertainty. The effects of inflation uncertainty and the relative price of capital are filtered through the user cost of capital which influences investment decisions. Domestic price and the movement of interest rates also have reflected some outcomes of the investors' perception of risks. Therefore, uncertainty in inflation may affect investment directly through the cost of capital or indirectly through domestic demand, which in turn affect the demand for capital.

Therefore, the full specification of the aggregate investment model can be written as:

$$
\begin{gathered}
\Delta i_{t}=\alpha+\beta_{0} \Delta i_{t-1}+\beta_{1} \Delta g d p_{t}+\beta_{2} \Delta g d p_{t-1}+\beta_{3} \Delta r p_{t}+\beta_{4} \Delta o p e n_{t}+\beta_{5} r l_{-} g d p_{t}+\beta_{6} \sigma g d p_{t}+\beta_{7} \sigma g d p_{t-1}+ \\
\beta_{8} \sigma i_{t}+\beta_{9} \sigma o p_{t-1}+\beta_{10} \sigma r p_{t} * \sigma C P I_{t}+\beta_{11} \sigma R E E R_{t} * \Delta \text { open }_{t}
\end{gathered}
$$

Where $\Delta i_{t}$ is the change in log private investment at time $t, \Delta g d p$ is the change in log demand, $\Delta r p$ is the change in $\log$ ratio of private investment deflator to GDP deflator or relative price of capital (proxy for the user cost of capital), open is the change in log ratio of exports plus imports to nominal GDP (proxy for the openness of the economy), $r l_{-} g d p$ is the log real loans to GDP (proxy for financial development), $\sigma g d p$ is uncertainty in demand, $\sigma i$ is uncertainty in interest rate, $\sigma o p$ is uncertainty in oil price, $\sigma r p$ is uncertainty in the relative price of capital, $\sigma C P I$ is uncertainty in domestic prices, and $\sigma R E E R$ is uncertainty in REER. The exogenous sources of uncertainty are REER and oil price, while GDP is endogenous to investment through the multiplier effect; and other endogenous sources of uncertainty are inflation, the relative price of capital or user cost of capital and interest rate.

Aggregate demand and user cost of capital may be endogenous to investment through the multiplier. Therefore OLS estimator for the behavioural parameters in the equation may be inconsistent. We adopt 2SLS approach and the GMM approach to address the endogeneity problems associated with the uncertainty variables. Other advantages of the GMM estimation are that (i) it does not require the normality assumption; (ii) it allows for unknown heteroskedasticity; (iii) it allows parameter estimation even if the model is analytically unsolvable based on first order conditions (Verbeek, 2004), and (iv) the GMM estimator is more efficient than the instrumental variable (IV) estimator in the presence of heteroskedasticity and is no worse asymptotically than the IV estimator in the absence of heteroskedasticity in the estimation (Baum et al., 2003). GMM is the preferred choice for modelling private investment behaviour to account for endogeneity and heteroskedasticity problems. In this study, we present the OLS and 2SLS results for comparison and robustness checking.

\subsection{The Estimation Strategy}

\subsubsection{Measuring Uncertainty}


This study uses the AR/ARMA models to test if the variances are homoskedastic. If variances are found to be heteroskedastic, GARCH/ARCH model will be used to generate the uncertainty variables. We use GARCH/ARCH statistical models to capture the dynamics of volatility. The merits of using the ARCH/GARCH model are highlighted by Byrne and Davis (2005b) as they argue that ARCH/GARCH offer more of the theoretical characteristic of uncertainty than an unconditional measure. The $\mathrm{ARCH} / \mathrm{GARCH}$ assumes that uncertainty changes people's perception and consequently, their responses to uncertainty (Note 6).

To generate the macroeconomic uncertainties, a 2-step approach is adopted: (i) estimate the best ARMA $(p, q)$ or ARIMA $(p, d, q)$ model using the Box Jenkins (1976) method; and (ii) check the errors for the presence of ARCH effects using the Lagrange multiplier (LM) (Engle, 1982). The ARCH LM statistic is computed from an auxiliary test regression to test the null hypothesis of no $\mathrm{ARCH}$ up to $p$ order. The lagged residuals in the ARCH test regression will be significant if ARCH effect is detected.

\subsubsection{Estimating the Investment Model}

This study adopts the GMM estimation approach which requires a selection of appropriate instruments. To test whether the instruments are independent of the unobservable errors, the model must be overly identified (moment of conditions $>$ number of parameters estimates). The Sargan's test of overidentifying restrictions shows whether the specification of the model is consistent with the joint validity of all the $L$ moment conditions. The overidentifying restrictions is tested through the commonly employed $J$-statistics of Hansen (1982) for GMM estimation to evaluate the suitability of the model. The $J$-statistic is distributed as $\chi^{2}$ distribution with d.o.f. equal to the number of overidentifying restrictions. The rejection of the null hypothesis means that the instruments do not satisfy the orthogonality conditions, either because the instruments are (i) not truly exogenous; or (ii) they are incorrectly excluded from the regression (Baum et al., 2003). In addition, the C-test or the Eichenbaum, Hansen and Singleton test examines whether a subset of instruments is orthogonal to the residuals for equations estimated by GMM. The C-test is calculated as the difference in $J$-statistics between the original equation and a secondary equation estimated using a subset of the total instruments. Similar to the C-test, the Regressor Endogeneity Test examines whether the subset of the endogenous variables is exogenous. The endogeneity test is calculated by comparing the $J$-statistics of the original estimate with the estimate which treats a set of endogenous variables as exogenous. The test is $\chi^{2}$ distributed with d.o.f. equal to the number of regressors tested for endogeneity.

\subsection{Data Source and the Data Generation Process}

Data on gross capital stock in nominal and constant prices, private investment deflator, GDP deflator, REER, t-o$t$, and oil price index (average spot price of UK Brent, Dubai and Alaskan, of equal weights) are collected from International Financial Statistics. Real interest rates (base lending rate minus inflation rate) and credit to GDP (proxy for financial depth) are collected from the Central Bank of Malaysia, and consumer price index (CPI), consumption of gross capital stock (depreciation), private investment in constant prices, GDP and lagged GDP (proxy for accelerator effect), and openness of economy [(total trade)/GDP as proxy for trade openness] are collected from the DOSM. The data set ranges from 1971 to 2010. Table 1 summarising variables used, their proxies, predicted signs and data sources.

Table 1. Explanatory Variables, Proxies, Predicted Signs and Data Sources.

\begin{tabular}{llll}
\hline Explanatory variable & \multicolumn{1}{c}{ Proxies } & $\begin{array}{l}\text { Predicted } \\
\text { sign }\end{array}$ & $\begin{array}{l}\text { Data } \\
\text { Source }\end{array}$ \\
\hline REER uncertainty & Exogenous shocks & - & IMF \\
T-o-t uncertainty & Exogenous shocks & - & IMF \\
Real interest rate uncertainty & Shocks to user cost of capital & - & BNM \\
Lagged oil price uncertainty & Shocks to user cost of capital & & IMF \\
Lagged private investment & $\begin{array}{l}\text { Lagged effects of investment } \\
\text { process }\end{array}$ & $+/-$ & DOSM \\
User cost of capital or relative price of capital & Cost of capital & - & DOSM \\
Real loan to GDP & Financial depth & + & BNM \\
Total trade/GDP & Trade openness & $+/-$ & DOSM \\
GDP and Lagged GDP & Accelerator effect & + & DOSM \\
\hline
\end{tabular}

Note: IMF denotes International Monetary Fund, DOSM denotes Department of Statistics Malaysia, and BNM denotes Bank Negara Malaysia (The Central Bank of Malaysia). *The uncertainty variables are generated from the statistical models described earlier. 
Uncertainty variables such as the interest rate, user cost of capital and relative price of capital use annual data, and, are generated using ARMA models. The application of the ARCH/GARCH approach is prevalent in situations where uncertainty changes over time. This study models uncertainty using the AR/ARMA model and test if the variances from the AR/ARMA model are homoskedastic. If variances are found to be heteroskedastic, the ARCH/GARCH model will be used to generate the uncertainty variables (Note 7). Table 2 shows the results of the data generation process. Results show that ARCH/GARCH effect is found in CPI, t-o-t, REER, oil price and GDP. To find the best AR/ARMA fit for CPI shows, Box Jenkins method shows that ARIMA $(7,1,6)$ yields the smallest Akaike Information Criterion, after eliminating the insignificant AR or MA terms. The ARCH LM test on the CPI data shows that it has ARCH effects. Another test such as a visual inspection of the correlogram of its square residuals also confirms the presence of $\mathrm{ARCH}$ effects (Note 8).

Table 2. ARMA/ARIMA and ARCH/GARCH Data Generation Process.

\begin{tabular}{lll}
\hline Variables (data frequency) & ARMA (p.q)/ARIMA (p,d,q) & ARCH(p)/GARCH(p,q) \\
\hline CPI & $(7,1,6)$ & $(3,1)$ \\
t-o-t & $(13,1,1)$ & $(1,1)$ \\
REER & $(5,1,8)$ & $(1,1)$ \\
Oil price & $(4,1,4)$ & $(2,1)$ \\
User cost of capital & $(8,8)$ & - \\
Relative price of capital & $(8,1,4)$ & - \\
Interest rate & $(7,1,8)$ & - \\
GDP & $(4,1,6)$ & $(1,1)$ \\
\hline
\end{tabular}

Note: If the ARCH effects cannot be detected from the time series data, the AR or ARMA will be used for the stationary series while the ARIMA will be used for the non-stationary series. However, if the macro series is found to be I(1), the best fitted ARIMA (p,d,q) model will be used instead of the AR or ARMA models. In order to generate the macroeconomic uncertainties, a 2-step approach is adopted to: (i) estimate the best ARMA(p,q) or ARIMA(p,d,q) model using the Box Jenkins (1976) method; and (ii) check the errors for the presence of ARCH effects using the Lagrange multiplier (LM) test (Engle, 1982).

\section{Findings}

\subsection{Prima Facie Evidence on the Impact of Uncertainty on Private Investment}

The Pearson correlation coefficients are shown in Table 3. There is a positive and significant relationship between the change in private investment $\left(\Delta i_{t}\right)$ and the change in GDP $(+0.820)$ and lagged change in GDP $(+0.361)$, suggesting the accelerator effect is closely related to aggregate private investment. Accelerator effects dictate that an increase in income accelerates capital accumulation. The negative correlations between loans to GDP ratio with the change in GDP and lagged GDP suggest that greater financial depth is negatively associated with output growth (Note 9). The negative relationship between the ratio of loans to GDP and interest rates (-0.394) shows that high interest rates is related to lower loans to GDP ratios. The significant negative relationship between the user cost of capital and the openness of the economy (-0.531) implies that the openness of the economy may be associated with an easy flow of funds, a greater access to external financing that can lower the cost of funds and the user cost of capital. The negative correlation coefficient of the user cost of capital and private investment of -0.269 is consistent with investment theory. The negative correlation between the user cost of capital and GDP (-0.289) is also consistent with expectations. Lower private investment is correlated with lower GDP as both tend to move in the same direction $(+0.820)$. In a nutshell, correlation analysis appears to support the view that the uncertainties are negatively correlated with private investment.

Table 3. Pearson Correlation Coefficient.

\begin{tabular}{llllllll}
\hline$\Delta g d p_{t}$ & $\Delta r p_{t}$ & $\Delta o p e n_{t}$ & $r_{t}$ & $r l g g d p_{t}$ & $\Delta u c_{t}$ & $\Delta i_{t}$ \\
\hline
\end{tabular}




\begin{tabular}{llllllll}
\hline$\Delta \mathrm{gdp}_{\mathrm{t}}$ & 1.0000 & & & & & & \\
$\Delta \mathrm{rp}_{\mathrm{t}}$ & -0.1136 & 1.0000 & & & & & \\
$\Delta \mathrm{open}_{\mathrm{t}}$ & 0.2507 & 0.2413 & 1.0000 & & & & \\
$\mathrm{r}_{\mathrm{t}}$ & 0.0197 & 0.0690 & 0.2149 & 1.0000 & & & \\
$\mathrm{rl} \mathrm{gdp}_{\mathrm{t}}$ & $-0.2858^{*}$ & -0.0541 & -0.1833 & $-0.3938^{* * *}$ & 1.0000 & & \\
$\Delta \mathrm{uc} \mathrm{t}_{\mathrm{t}}$ & $-0.2888^{*}$ & -0.0609 & $-0.5309^{* * *}$ & -0.0001 & 0.0394 & 1.0000 & \\
$\Delta \mathrm{i}_{\mathrm{t}}$ & $0.8203^{* * *}$ & -0.0273 & 0.2497 & -0.0922 & $-0.2722^{*}$ & $-0.2691^{*}$ & 1.0000 \\
\hline
\end{tabular}

Note: $\Delta \mathrm{gdp}$ is the change in GDP. $\Delta \mathrm{rp}_{\mathrm{t}}$ is the change in the price of capital, $\Delta \mathrm{open}_{\mathrm{t}}$ is the change in the degree of openness of the economy, $\mathrm{r}_{\mathrm{t}}$ is interest rate, $\Delta \mathrm{rl}$ gdp $\mathrm{p}_{\mathrm{t}}$ is the change in the ratio of real loans to GDP and $\Delta \mathrm{uc}_{\mathrm{t}}$ is the change in user cost of capital. $\Delta \mathrm{i}_{\mathrm{t}}$ and $\Delta \mathrm{i}_{\mathrm{t}-1}$ are the change in private investment and lagged private investment respectively. ${ }^{* * *}, * * *$ represent statistical significance at $10 \%, 5 \%$ and $1 \%$, respectively.

\subsection{Unit Root Tests}

Perron (1989) argued that the presence of a structural break caused by shocks will lead to the conventional ADF tests biased towards the non-rejection of the null hypothesis of unit root. While Perron (1989) shows that the failure to allow for an existing break leads to a bias that compromises the ability to reject a false unit root null hypothesis, the assumption of a known break date or an exogenously structural break is subject to numerous criticisms (See Christiano, 1992; Banerjee, Lumsdaine and Stock, 1992). To address this issue, this study carries out Vogelsang and Perron (VP, 1998) and the Zivot and Andrews (ZA, 1992), who treat the occurrence of the break date as unknown, in addition to the conventional Augmented Dickey-Fuller (ADF) tests (Dickey and Fuller, 1979 and 1981) and Phillips-Perron (1988). ZA and VP tests found that the relative price of capital and the user cost of capital were trend stationary with a break in 1986 and 1988, respectively. However, both tests are unable to detect any breaks for the oil price, REER, interest rate, t-o-t and GDP (See Table 4).

Table 4. Unit Root Tests.

\begin{tabular}{lllll}
\hline Variables & $\begin{array}{l}\text { ADF test } \\
\boldsymbol{H}_{\mathbf{0}} \text { : Unit root }\end{array}$ & $\begin{array}{l}\text { PP test } \\
\boldsymbol{H}_{\mathbf{0}} \text { : Unit root }\end{array}$ & $\begin{array}{l}\text { ZA test } \\
\boldsymbol{H}_{\mathbf{0}} \text { : Unit root } \\
\boldsymbol{H}_{\mathbf{1}} \text { : stationary with one time } \\
\text { trend break at unknown point }\end{array}$ & $\begin{array}{l}\text { VP test } \\
\boldsymbol{H}_{\mathbf{0}} \text { : Unit root } \\
\boldsymbol{H}_{\mathbf{1}} \text { : stationary with trend break }\end{array}$ \\
\hline CPI & $\mathrm{I}(0)$ & $\mathrm{I}(0)$ & $\mathrm{I}(0)$, Break: 1981 & Unit root \\
uc & $\mathrm{I}(0)$ & $\mathrm{I}(0)$ & $\mathrm{I}(0)$, Break: 1988 & $\mathrm{I}(0)$, Break: 1988 \\
rp & $\mathrm{I}(1)$ & $\mathrm{I}(1)$ & $\mathrm{I}(0)$, Break: 1986 & $\mathrm{I}(0)$, Break: 1986 \\
$\mathrm{r}$ & $\mathrm{I}(1)$ & $\mathrm{I}(1)$ & Unit root & Unit root \\
t-o-t & $\mathrm{I}(0)$ & $\mathrm{I}(0)$ & Unit root & Unit root \\
REER & $\mathrm{I}(1)$ & $\mathrm{I}(1)$ & Unit root & Unit root \\
op & $\mathrm{I}(1)$ & $\mathrm{I}(1)$ & Unit root & Unit root \\
GDP & $\mathrm{I}(1)$ & $\mathrm{I}(1)$ & Unit root & Unit root \\
\hline
\end{tabular}

Note: CPI denotes consumer price index, uc denotes user cost of capital, rp denotes relative price of capital, $r$ denotes interest rates, t-o-t denotes terms of trade, REER denotes real effective exchange rate, op denotes oil price, and GDP denotes Gross Domestic Product. ADF, PP, VP and ZA denote Augmented Dickey-Fuller (Dickey and Fuller, 1979 and 1981), Phillips-Perron (1988), Vogelsang and Perron (1998) and Zivot and Andrews (1992) trendbreak stationarity tests, respectively. The monthly time series of the CPI, t-o-t, REER and the oil price are used in the data generating process for uncertainty. The monthly series are used (if and when available) as a larger number of observations could: (i) circumvent the loss in degrees of freedom and; (ii) optimise the use of information contained in the monthly data. All variables except for interest rate (r) are tested in logarithm form. The year which a break in trend occurs will be specified; otherwise it will be left blank.

\subsection{The Estimation Models}

A comparison of the results of all the estimation models of OLS, 2SLS and the GMM estimates (both Iterative weights and 2 steps iterations) (Table 5). Compared OLS, 2SLS, GMM (iterative weights) and GMM (2-Step iteration) results in columns 1,2,3, and 5, respectively, the iterative weights GMM model in column 3 is the preferred model. All the signs of all the coefficients are consistent with theory and they are able to significantly explain the change in private investment. 
Table 5. The Estimation Approaches.

\begin{tabular}{|c|c|c|c|c|c|c|}
\hline \multirow[t]{3}{*}{ Variables } & \multirow[t]{3}{*}{ OLS } & 2 SLS & \multicolumn{2}{|c|}{ GMM $\quad$ GMM $^{\#}$} & \multicolumn{2}{|c|}{ GMM $\quad$ GMM $^{\#}$} \\
\hline & & & Iterative $\mathrm{w}$ & ights & 2-Step iter & tion \\
\hline & & (2) & (3) & (4) & (5) & (6) \\
\hline$\Delta \mathrm{i}_{\mathrm{t}-1}$ & -0.2032 & -0.06013 & $-0.1560^{* *}$ & $-0.1667^{*}$ & -0.1017 & -0.0900 \\
\hline$\Delta \mathrm{gdp}_{\mathrm{t}}$ & $+1.413^{*}$ & +0.6763 & +0.1554 & +0.3409 & +0.4418 & $+0.9926^{*}$ \\
\hline$\Delta \mathrm{gdp}_{\mathrm{t}-1}$ & $+2.4401^{* *}$ & +1.7817 & $+2.7993^{* * *}$ & $+2.4104^{* * *}$ & $+1.8835^{* * *}$ & $+1.8051^{*}$ \\
\hline$\Delta \mathrm{rp}_{\mathrm{t}}$ & -0.6477 & -1.0425 & $-0.9069^{* * *}$ & - & $-0.9891^{* * *}$ & \\
\hline $\mathrm{uc}_{\mathrm{t}}$ & - & - & - & +0.0610 & - & +0.0500 \\
\hline$\Delta$ open $_{t}$ & $+1.4508^{* * *}$ & $+1.3238^{* *}$ & $+1.6237^{* * *}$ & $+2.1038^{* * *}$ & $+1.5087^{* * *}$ & $+1.5752^{* * *}$ \\
\hline $\mathrm{rl} \_\mathrm{gdp} \mathrm{t}_{\mathrm{t}}$ & +0.0381 & -0.0161 & $+0.0729^{* *}$ & $+0.1632^{* * *}$ & +0.0301 & +0.0899 \\
\hline$\sigma \mathrm{gdp}_{\mathrm{t}}$ & -0.0009 & +0.0007 & $-0.0027^{* * *}$ & $-0.0061^{* * *}$ & -0.0009 & -0.0020 \\
\hline$\sigma \mathrm{gdp}_{\mathrm{t}-1}$ & -0.0027 & -0.0047 & -0.0021 & $-0.0056^{* * *}$ & $-0.0040^{* * *}$ & $-0.0057^{* *}$ \\
\hline$\sigma r_{t}$ & $-0.0704^{* *}$ & -0.0370 & $-0.0566^{* * *}$ & $-0.0849^{* * *}$ & $-0.0652^{* * *}$ & $-0.0616^{* * *}$ \\
\hline$\sigma \mathrm{op}_{\mathrm{t}-1}$ & -1.8756 & +0.4462 & $-1.9945^{* *}$ & -1.4475 & -1.8982 & -0.1678 \\
\hline$\sigma \mathrm{rp}_{\mathrm{t}} * \sigma \mathrm{cpi}_{\mathrm{t}}$ & -0.0154 & $-0.0410^{*}$ & $-0.0293^{* * *}$ & $-0.0183^{* * *}$ & $-0.0345^{* * *}$ & $-0.0249^{* * *}$ \\
\hline $\boldsymbol{\sigma r e e r}_{\mathrm{t}} * \Delta$ open $_{\mathrm{t}}$ & $-0.1778^{* * *}$ & $-0.1974^{* * *}$ & $-0.2198^{* * *}$ & $-0.2031^{* * *}$ & $-0.2134^{* * *}$ & $-0.1817^{* * *}$ \\
\hline$R^{2}$ & 0.9185 & 0.8704 & 0.8949 & 0.8495 & 0.8959 & 0.8826 \\
\hline $\boldsymbol{J}$-statistic ( $\boldsymbol{p}$-val) & - & 0.9210 & 0.7827 & 0.7672 & 0.6917 & 0.6327 \\
\hline$S S R$ & 0.1276 & 0.2010 & 0.1631 & 0.2335 & 0.1614 & 0.1821 \\
\hline
\end{tabular}

Note: ${ }^{* * * * * * *}$ represent statistical significance at $10 \%, 5 \%$ and $1 \%$, respectively. $\mathrm{GMM}^{\#}$ denotes this investment model is estimated with user cost of capital (for robustness checking). $\Delta i_{t}$ is the change in log private investment at time $t, \Delta g d p$ is the change in log demand, $\Delta r p$ is the change in log ratio of private investment deflator to GDP deflator or relative price of capital (proxy for the user cost of capital), uc is user cost of capital, $\Delta$ open is the change in log ratio of exports plus imports to nominal GDP (proxy for the openness of the economy), $r l_{-} g d p$ is the log real loans to GDP (proxy for financial development), $\sigma g d p$ is uncertainty in demand, $\sigma i$ is uncertainty in interest rate, $\sigma o p$ is uncertainty in oil price, $\sigma r p$ is uncertainty in the relative price of capital, $\sigma C P I$ is uncertainty in domestic prices, and $\sigma R E E R$ is uncertainty in real effective exchange rate. SSR denotes sum square residuals.

The estimated coefficients of the GMM model are consistent with economic theory. However, the changes in the size of coefficients are more apparent compared to the changes seen in the OLS and IV estimates. The income accelerator effects represented by $\Delta \mathrm{gdp}$ and $\Delta \mathrm{gdp}_{\mathrm{t}-1}$ have a positive effect on the change in private investment. The change in lagged GDP is estimated to increase private investment by 2.799 percentage points while the change in current GDP has a positive but insignificant impact. The accelerator coefficient appears to be larger than Guimaraes and Unteroberdoerster (2006) and Ang (2010)'s estimation of +0.52 to +1.5 percent for the change in GDP on private investment in Malaysia. The size of the estimated coefficient for lagged GDP and GDP in other studies (e.g., Servén, 1998; Jongwanich and Kohpaiboon, 2008; Solimano, 1992) exceeds unity, suggests that demand tends to be a significant determinant of private investment for most countries.

The sign of the estimated relative price of capital is negative, implying that the real rental cost of capital has a significant long-run negative effect on the change in investment. The size of the coefficient indicates that the relative price of capital has a more modest impact on private investment compared with output. Results show that an increase of 1 percentage point in the relative price of capital is expected to decrease private investment by 0.907 percentage point. This result is in line with Roache (2006), Eisner and Nadiri (1968), and Chirinko (1993) who found the elasticity of capital with respect to prices to be below unity. The size of the coefficient supports the notion that output effects tend to be stronger than price effects.

The significant positive estimated coefficient of real loans to GDP ratio of 0.073 suggests that the depth of the financial system has a positive impact on private investment. While the sign of the estimated coefficient is also consistent with some empirical studies (e.g., Ghura and Goodwin, 2000; Servén, 1998; TunWai and Wong, 1982), the size of the coefficient in this study is relatively smaller. This small coefficient suggests that the financial system plays an important role but its importance may be tempered by the development of the capital markets and the availability of cross-border financing. TunWai and Wong (1982) estimated the impact of domestic credit on investments to be +1.18 for Malaysia, stronger than the estimated coefficient in this study. The discrepancy in the 
size of the estimate could be due to the growing importance of non-bank-based capital financing in Malaysia over the years.

The coefficient of the uncertainty in interest rates, as an indication of the availability of financing, is negative and significant in all the models except the 2SLS model. Interest rates uncertainty reduces private investment by 0.057 percentage points. The size of the estimated coefficient of interest rate uncertainty suggests that the uncertainties emanating from external sources, such as REER uncertainty, may not be fully transmitted through the financing channels. The importance of financial sector development is shown by Aysan et al. (2009) where their structural reform index (which includes financial sector development and the trade openness of a country) has a positive relationship with investments that offset some of the negative impact of economic volatility.

The openness of the economy is positively related to the change in private investment, with a one percentage point change in the degree of openness resulting in a 1.62 percentage point increase in private investment. The openness of the economy promotes competition and enhances the transference of technology through investment. While an open economy benefits from the cross-border exchanges of knowledge and technology, the openness also exposes the economy to external shocks. The negative coefficient $(-0.220)$ of the interaction term of REER and the openness $\left(\right.$ (reer $_{t} *$ open $\left._{t}\right)$ underscores the vulnerability effect. However, the transmission of the negative effects of REER is mitigated by the depth of the financial sector and the positive benefits derived from the cross-border trade. Our study is consistent with Servén's (2003) where the negative relationship of REER and investments tend to be accentuated by the low financial depth of a country as a poorly developed financial system makes it difficult for investors to diversify risks (Note 10). The impact of oil price uncertainty is significant in the GMM estimates of the model which includes the relative price of capital into the model specification but insignificant for the OLS and 2SLS model estimates.

The 2SLS model also performs worse than the GMM model as it produces only three coefficients which are significant compared to the GMM model which shows more significant coefficients. Between the two GMM methods, the iterative weights GMM appears to perform better for the equation which uses the relative price of capital as the explanatory variable for private investment.

\subsection{Robustness Tests and Diagnostic Checking}

For robustness tests, we re-estimate the GMM models (both iterative weights and 2-step iteration) with user cost of capital in its speciation, and results are depicted in Table 5 [column (4) and (6)], respectively. The sign of the coefficient for user cost of capital is insignificant for both GMM estimation methods, despite the 2-step GMM model producing a smaller $S S R$ for the investment equation. GMM model has passed a battery of tests. First, the $J$-statistics cannot reject the null hypothesis of over identifying restrictions for all estimation approaches. The model is valid and the data meet the requirements of the restrictions. Second, C-test shows that the subset of instruments is exogenous and orthogonal to the error term. Hence, the chosen instrument is valid in the GMM estimation. Third, endogeneity might be an issue in the model as aggregate demand are endogenous to investment through the multiplier effect and the user cost of capital may also be endogenous in the investment equation. We have accounted for endogeneity problem proposed by Wooldridge (2006). The regressors should not be treated as exogenous variables as the null hypothesis in the Regressor Endogeneity Test cannot be rejected. Therefore, appropriate instruments should be used to represent them (C-test and Regressor Endogeneity Test results are not Tabled here, but is available upon request). We have also examined the correlation between the uncertainty variables are less than 0.5 , with the exception of uncertainty in user cost of capital and cpi, this suggests low multicollinearity amongst the variables.

\subsection{Assessing the Impact of Uncertainty}

The impact of uncertainties on private investment is depicted in Table 6. In assessing the estimated impact of uncertainties on private investment, the negative of the uncertainty in demand appears to have a significant impact. At the mean values, uncertainty in demand $(-0.014)$ and its lag $(-0.011)$ have cumulative effect of -0.025 . This suggests that a 10 percentage increase in demand uncertainty will reduce private investment by 0.250 percentage points. The sign of the coefficients for uncertainty in demand is consistent but the size of the estimated coefficient is different from other studies such as Hakim (2008) and Ang (2010) who estimated demand uncertainty to be 0.003 and -0.10 respectively for Malaysia. Aysan et al. (2009) and Driver and Moreton (1991) also found that the estimated coefficient for demand uncertainty to be relatively small, -0.02 and -0.08 respectively.

Table 6. The Impact of Uncertainty on Private Investment.

\begin{tabular}{llllll}
\hline Variables & Estimated & Mean of & 1 & Impact at mean & 1 stdev impact \\
\hline
\end{tabular}




\begin{tabular}{|c|c|c|c|c|c|}
\hline & coefficient & ${ }^{\wedge} \mathrm{CV} / \mathrm{UV}$ & stdev & values & from mean \\
\hline$\sigma g d p_{t}$ & $-0.0027^{* * *}$ & 5.0707 & 8.5975 & -0.0137 & -0.0232 \\
\hline$\sigma g d p_{t-1}$ & -0.0021 & 5.1998 & 8.6705 & -0.0109 & -0.0255 \\
\hline$\sigma r_{t}$ & $-0.0566^{* * *}$ & 0.5338 & 0.6157 & -0.0302 & -0.0361 \\
\hline$\sigma o p_{t-1}$ & $-1.9945^{* *}$ & 0.0129 & 0.0191 & -0.0257 & -0.0433 \\
\hline oreer $_{t}$ & - & 3.8963 & 6.2693 & - & - \\
\hline$\sigma r p_{t}$ & - & 0.5669 & 0.7433 & - & - \\
\hline$\sigma \operatorname{rp}_{\mathrm{t}}^{*} \sigma c \mathrm{i}_{\mathrm{t}}$ & $-0.0293^{* * *}$ & & & -0.0465 & -0.0601 \\
\hline oreer $_{t}{ }^{*} \Delta$ open $_{t}$ & $-0.2198^{* * *}$ & & & $-0.0162^{\#}$ & $-0.0261^{\#}$ \\
\hline $\begin{array}{l}\text { Sum of external } \\
\text { shocks }\end{array}$ & & & & $-0.0419^{\#}$ & $-0.0643^{\#}$ \\
\hline $\begin{array}{l}\text { Sum of internal } \\
\text { shocks }\end{array}$ & & & & -0.0904 & -0.1181 \\
\hline
\end{tabular}

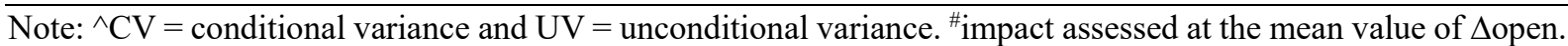
$*, * *, * * *$ denote significance at $10 \%, 5 \%$, and $1 \%$, respectively.

The overall impact of internal shocks appears to be larger than the impact of external shocks. However, it is difficult to isolate the impact of a single shock as it is usually related to other forms of shocks and they may feedback into one another. The impact of oil price uncertainty (-0.026) may be relatively small as it may already have manifested itself in demand and terms-of-trade uncertainties. Meanwhile, the impact of oil price uncertainty appears to be stronger than the impact of interest rate uncertainty during 1981-1984, when there was a sharp decline in the oil price and in 1993-1995 when the Malaysian economy was experiencing very robust growth, averaging $9.7 \%$ during this period. The impact of oil price uncertainty on private investments appears to be significant during 1985-1986 (following a sharp fall in oil prices, and the collapse in commodity prices) and during 1993-1997 (following the global recession in 1991-1993) and this results in a severe loss of income for Malaysia. However, the impact of oil price uncertainty and demand uncertainty on private investment appear to be equally strong post-AFC.

Uncertainty in interest rates (an internal shock), evaluated at mean, significantly reduce private investment by 0.030 percentage points. A one standard deviation increase in uncertainty in interest rates will reduce private investment by 0.036 percentage points. This result is marginally close to the one standard deviation impact estimated by Byrne and Davis's (2005a) study that show estimated values within -0.021 to -0.035 . The interaction term of the relative price of capital and domestic prices has a significant negative impact on private investment. The Pearson correlation coefficient between uncertainty in the relative price of capital and uncertainty in domestic prices is negative (-0.055). Therefore, it appears that uncertainty in the price of capital does not worsen the uncertainty in domestic prices as they move in different directions. The offsetting forces of both uncertainties explain a relatively modest overall effect on private investment.

The impact of REER uncertainty on investment was more pronounced during the periods 1987-1991, 1993-1995 and 1997-1999. The first two periods coincided with the liberalisation of some of Malaysia's exchange control measures in 1987 and 1994-96. An increase in the openness of the economy coincides with the higher REER uncertainty, suggesting that the transmission of REER uncertainty into investment activities is stronger with the increasing degree of the openness of the economy and, this is particularly evident during the AFC period.

A comparison of the overall impact of internal and external uncertainties shows that the impact of external uncertainties on private investment is smaller compared to the impact of internal uncertainties. The results suggest that despite being vulnerable to external risks, the benefits of being an open economy outweigh the risks.

\section{Conclusion}

This study examines the effect of uncertainty on private investment for Malaysia using the ARCH/GARCH approach and GMM estimation for a period from 1971-2010. This study provides empirical evidence that private investments do not only respond to the conventional determinants of investment such as the relative price of capital and demand, but also to macroeconomic uncertainties. With the incorporation of macro uncertainty variables, we could explain why investments remained modest and were less responsive to the improvements in the investment climate, especially after the AFC. Firms delay investments during periods of uncertainty as they remain cautious and uncertain about the prospects of demand and prices. Therefore, this study provides evidence to support the argument that macroeconomic uncertainties influence the firms' forward-looking investment decision making process.

The demand and lagged demand uncertainties have a relatively stronger effect on investments compared with other 
macro uncertainties, suggest that demand tends to be a significant determinant of private investment in Malaysia. The structure of the economy, the depth of the financial system, and the promotion of trade openness abates the negative impact of uncertainty on investment. A greater financial sector depth allows risk diversification while the openness of an economy promotes competition.

The benefits of being an open economy outweigh the costs of being exposed to the REER uncertainty up to a point when the REER uncertainty becomes larger than two standard deviations. This suggests that as long as the REER uncertainty is low, it is still beneficial for the government to promote trade openness, which can encourage greater efficiency through competition and cross-border exchange of knowledge, skills and technology. Furthermore, the degree of the impact of exchange rate uncertainty would depend on the substitutability of capital and the import content of private investments. Malaysia is highly dependent on imported intermediate inputs. Therefore, the reduction of Malaysia's dependency of imported capital and intermediate inputs is encouraged.

Study also shows the elasticity of the user cost of capital to be less than unity, suggesting that there is limited scope for the government to encourage investment through tax incentives, nonetheless counter-cyclical fiscal policy may be crucial during periods of economic stress as it helps in alleviating pessimistic expectations. The size of the coefficient supports the notion that output effects tend to be stronger than price effects.

There is limitation of the study. This study assumes that the different financing cost would have already been reflected in the firm's interest expense item. To reflect the true financing cost for a firm, future research can focus on a more reliable assessment of the impact of the user cost of capital using micro panel data analysis whereby biasness resulting from aggregation over firms or individuals may be reduced or eliminated (Baltagi, 2008).

The results of the study suggest that the government's policies directed at encouraging investments need to be more broad-based. While the role of fiscal policy remains an integral part of macro management, attention should also be given to managing risks perception and uncertainties. Policies which emphasise on achieving stability and sustainability in economy are equally important in helping the private sector make efficient and profitable investment decisions.

\section{Acknowledgments}

We dedicate this work to the memory of the late Dr. Balachandher Krishnan Guru for his guidance and patience. The authors are grateful to Professor A. Rambaldi and Professor Lee Cassey for their insightful comments and suggestions. The usual disclaimers apply. We would like to acknowledge FRGS grant scheme (FRGS 1/2015/SS05/ MUSM/02/2), Ministry of Higher Education, for the financial support to publish this article.

\section{References}

Aizenman, J., \& Marion, N. P. (1993). Policy uncertainty, persistence and growth. Review of International Economics, 1(2), 145-163. https://doi.org/10.1111/j.1467-9396.1993.tb00012.x

Aizenman, J., \& Marion, N. P. (1999). Volatility and investment: Interpreting evidence from developing countries. Economica, 66(262), 157-179. https://doi.org/10.1111/1468-0335.00163

Aizenman, J., \& Pinto, B. (2005). Managing economic volatility and crises. A Practitioner's Guide. United States: Cambridge University Press.

Ang, J. (2010). Determinants of private investment in Malaysia: What causes the post-crisis slumps? Contemporary Economics Policy, 28(3), 378-391. https://doi.org/10.1111/j.1465-7287.2009.00155.x

Aysan, A., Pang, G., \& Veganzones-Varoudakis, M. A. (2009). Uncertainty, economic reforms and private investment in the Middle East and North Africa. Journal of Applied Economics, 41, 1379-1395. https://doi.org/10.1080/00036840601019315

Baltagi, B. H. (2008). Econometric analysis of panel data (4th ed.). England: John Wiley \& Sons Ltd.

Banerjee, A., Lumsdaine, R. L., \& Stock, J. H. (1992). Recursive and sequential tests for a unit root: Theory and international evidence. Journal of Business and Economic Statistics, 10, 271-287. Retrieved from https://scholar.harvard.edu/files/stock/files/recursive_and_sequential_tests_of_the_unit_root_and_trend_bre ak_hypotheses_theory_and_international_evidence.pdf

Bank Negara Malaysia. (1999). The Central Bank and the financial system in Malaysia: A decade of change, 1989 -1999 (1st ed.). Kuala Lumpur: Bank Negara Malaysia.

Baum, C. F., Schaffer, M. E., \& Stillman, S. (2003). Instrumental variables and GMM: Estimation and testing. The Stata Journal, 1(3), 1-31. https://ageconsearch.umn.edu/bitstream/116029/2/sjart_st0030.pdf

Bernanke, B.S. (1983). Irreversibility, uncertainty and cyclical investment. Quarterly Journal of Economics, 98(1), 
85-106. https://doi.org/10.2307/1885568

Bloom, N., Bond, S., \& Van Reenen, J. (2007). Uncertainty and investment dynamics. Review of Economic Studies, 74, 391-415. https://doi.org/10.1111/j.1467-937X.2007.00426.x

Box, G. E. P., \& Jenkins, G. M. (1976). Time series analysis: Forecasting and control (Rev ed.). San Francisco Holden-Day.

Byrne, J. P., \& Davis, E. P. (2005a). Investment and uncertainty in the G7. Review of World Economics, 141(1), 132. https://doi.org/10.1007/s10290-005-0013-0.

Byrne, J. P., \& Davis, E. P. (2005b). The impact of short- and long-run exchange rate uncertainty on investment: A panel study of industrial countries. Oxford Bulletin of Economics and Statistics, 67(3), 307-329. https://doi.org/10.1111/j.1468-0084.2005.00121.x

Caballero, R. J. (1991). On the sign of the investment-uncertainty relationship. American Economic Review, 81(1), 279-288. Retrieved from https://www.jstor.org/stable/2006800

Caballero, R. J. (2000). Structural volatility in Mexico: A policy report (Working Paper 420). Washington: InterAmerican Development Bank (IADB), Research Department. Retrieved from http://citeseerx.ist.psu.edu/viewdoc/download?doi=10.1.1.196.2333\&rep=rep1\&type=pdf

Caballero, R. J. (2001). Macroeconomic volatility in Latin America: A view and three case studies. Estudios de Economia, 28, 5-52. Retrieved from http://econ.uchile.cl/uploads/publicacion/5dbbe2cb-31e3-4b7d-b2ddfaa60a827a05.pdf

Campa, J., \& Goldberg, L. S. (1995). Investment in manufacturing, exchange rates and external exposure. Journal of International Economics, 38, 297-320. https://doi.org/10.1016/0022-1996(94)01348-V

Carruth, A., Dickerson, A., \& Henley, A. (2000). What we know about investment under uncertainty. Journal of Economic Surveys, 14, 119-153. https://doi.org/10.1111/1467-6419.00107

Chirinko, R. S. (1993). Business fixed investment spending: Modeling strategies, empirical results, and policy implications. Journal of Economic Literature, 31(4), 1875-1911. Retrieved from https://www-jstororg.ezproxy.lib.monash.edu.au/stable/2728330

Christiano, L. J. (1992). Searching for a break in GNP. Journal of Business and Economic Statistics, 10(3), 237249. https://doi.org/10.2307/1391540

Darby, J., Hallett, A. H., Ireland, J., \& Piscitelli, L. (1999). The impact of exchange rate uncertainty on the level of investment. The Economic Journal, 109(454), C55-C67. https://doi.org/10.1111/1468-0297.00416

Dickey, D. A., \& Fuller, W. A. (1979). Distribution of the estimators for autoregressive time series with a unit root. Journal of the American Statistical Association, 74, 427-431. https://doi.org/10.2307/2286348

Dickey, D. A., \& Fuller, W. A. (1981). Likelihood ratio statistics for autoregressive time series with a unit root. Econometrica, 49, 1057-1072. https://doi.org/10.2307/1912517

Dixit, A. K., \& Pindyck, R. S. (1994). Investment under uncertainty. United States: Princeton University Press.

Driver, C., \& Moreton, D. (1991). The influence of uncertainty on UK manufacturing investment. Economic Journal, 101(409), 1452-1459. https://doi.org/10.2307/2234895

Easterly, W., Islam, R., \& Stiglitz, J. E. (2000). Shaken and stirred: Explaining growth volatility. Annual World Bank Conference on Development Economics, 191-211. Retrieved from http://www.rrojasdatabank.info/wbdevecon00-12.pdf

Eisner, R., \& Nadiri, I. M. (1968). Investment behaviour and neoclassical theory. The Review of Economics and Statistics, 50(3), 369-382. https://doi.org/10.2307/1937931

Engle, R. F. (1982). Autoregressive conditional heteroskedasticity with estimates of the variance of United Kingdom inflation. Econometrica, 50(4), 987-1007. https://doi.org/10.2307/1912773

Ferderer, P. J. (1993). The impact of uncertainty on aggregate investment spending: An empirical analysis. Journal of Money, Credit and Banking, 25(1), 30-48. https://doi.org/10.2307/2077818

Fielding, D. (1997). Aggregate investment in South Africa: A model with empirical implications for political reform. Oxford Bulletin of Economics and Statistics, 59(3), 349-369. https://doi.org/10.1111/14680084.00070

Ghura, D., \& Goodwin, B. (2000). Determinants of private investment: A cross regional empirical investigation. 
Applied Economics, 32, 1819-1829. https://doi.org/10.1080/000368400425044

Gisser, M., \& Goodwin, T. H. (1986). Crude oil and the macroeconomy: Tests of some popular notions. Journal Money, Credit \& Banking, 18(1), 95-103. https://www.jstor.org/stable/1992323 doi: 10.2307/1992323

Guimaraes, R., \& Unteroberdoerster, O. (2006). What's driving private investment in Malaysia? Aggregate trends and firm-level evidence, IMF Working Paper No. WP/06/190. Washington: International Monetary Fund. https://doi.org/10.5089/9781451864502.001

Guiso, L., \& Parigi, G. (1999). Investment and demand uncertainty. The Quarterly Journal of Economics, 114(1), 185-227. https://doi.org/10.1162/003355399555981

Guo, H., \& Kliesen, K.L. (2005). Oil price volatility and US macroeconomic activity. Federal Reserve Bank of St Louis Review, 87(6), 669-83. $\quad$ Retrieved from https://files.stlouisfed.org/files/htdocs/publications/review/05/11/KliesenGuo.pdf

Hakim, I. S. (2009). Investment in Malaysia in the post-crisis era: Issues and challenges. In V. Lim, \& Min B. Shrestha (Eds.), Investment in the SEACEN Countries in the Post-Crisis Era: Issues and Challenges (pp. 113145). Kuala Lumpur: The South-East Asian Central Banks (SEACEN) Research and Training Centre.

Hall, R.E., \& Jorgenson, D.W. (1967). Tax policy and investment behaviour. American Economic Review, 57(3), 391-414. Retrieved from http://www.jstor.org/stable/1812110

Hansen, L. P. (1982). Large sample properties of generalised method of moments estimators. Econometrica, 50, 1029-1054. https://doi.org/10.2307/1912775

Hartman, R. (1972). The effects of price and cost uncertainty on investment. Journal of Economic Theory, 5(2), 258-266. https://doi.org/10.1016/0022-0531(72)90105-6

Hnatkovska, V., \& Loayza N. (2005). Volatility and growth. In J. Aizenman, \& B. Pinto (Eds.), Managing economic volatility and crises (pp. 65-98). United States: Cambridge University Press.

Huizinga, J. (1993). Inflation uncertainty, relative price uncertainty and investment in US manufacturing. Journal of Money, Credit \& Banking, 25(3), 521-549. https://doi.org/ 10.2307/2077721

Jongwanich, J., \& Kohpaiboon, A. (2008). Private investment: Trends and determinants in Thailand. World Development, 36, 1709-1724. https://doi.org/10.1016/j.worlddev.2008.01.010

Jorgenson, D.W. (1963). Capital theory and investment behaviour. American Economic Review, 53, 247-259. Retrieved from https://www.jstor.org/stable/1823868

Levine, R., \& Zervos, S. (1998). Stock markets, banks and economic growth. American Economic Review, 88(3), 537-558. Retrieved from https://www.jstor.org/stable/116848

Perron, P. (1989). The great crash, the oil price shock and the unit root hypothesis. Econometrica, 57(6), 13611401. https://doi.org/10.2307/1913712

Phillips, P. C. B., \& Perron P. (1988). Testing for a unit root in time series regression. Biometrika, 75, 335-346. https://doi.org/10.2307/2336182

Pindyck, R. S. (1988). Irreversible investment, capacity choice and the value of the firm. American Economic Review, 78(5), 969-985. Retrieved from https://www.jstor.org/stable/1807160

Price, S. (1995). Aggregate uncertainty, capacity utilization and manufacturing investment. Applied Economics, 27, 147-154. https://doi.org/10.1080/00036849500000017

Rajan, R. G., \& Zingales, L. (1998). Financial dependence and growth. American Economic Review, 88(3), 559586. Retrieved from https://www.jstor.org/stable/116849

Ramey, G., \& Ramey, V. (1995). Cross-country evidence on the link between volatility and growth. American Economic Review, 85(5), 1138-1150. Retrieved from http://www.jstor.org/stable/2950979

Roache, S. K. (2006). Domestic investment and the cost of capital in the Caribbean. IMF Working Paper WP/06/152. Retrieved from https://www.imf.org/external/pubs/ft/wp/2006/wp06152.pdf

Samuel, C. (1996). The investment decision: A re-examination of competing theories of panel data. Policy Research Working Paper 1654. Washington: The World Bank. Retrieved from http://documents.worldbank.org/curated/en/518521468760578857/The-investment-decision-a-reexamination-of-competing-theories-using-panel-data

Servén, L. (1998). Macroeconomic uncertainty and private investment in LDCs: An empirical investigation. 
Working Paper Series WP 2035. Washington: The World Bank. Retrieved from http://documents.worldbank.org/curated/en/420401468741328458/Macroeconomic-uncertainty-andprivate-investment-in-developing-countries-an-empirical-investigation

Servén, L. (2003). Real exchange rate uncertainty and private investments in LDCS. The Review of Economic and Statistics, 85(1), 212-218. https://doi.org/10.1162/rest.2003.85.1.212

Solimano, A. (1992). How private investment reacts to changing macroeconomic conditions: The case of Chile in the 1980s. In A. Chhibber, M. Dailami, \& N. Shafik (Eds). Reviving private investment in developing countries. Empirical studies and policy lessons (pp.19-42). United States: North-Holland.

Temple, P., Urga, G., \& Driver, C. (2001). The influence of uncertainty on investment in the UK: A macro or micro phenomenon? Scottish Journal of Political Economy, 48(4), 361-382. https://doi.org/10.1111/14679485.00204

The World Bank (1970). The current economic position and prospects of the Federation of Malaya, vol.2 (Report: EAP-11a). Washington: The Department of Operations, Far East, The World Bank.

The World Bank (2011). Malaysian economic monitor: Brain drain. Washington: United States.

TunWai, U., \& Wong, C. (1982). Determinants of private investment in developing countries. Journal of Development Studies, 19, 19-36. https://doi.org/10.1080/00220388208421848

Verbeek, M. (2004). A guide to modern econometrics (2nd ed.). United Kingdom: John Wiley \& Sons.

Vogelsang, T. J., \& Perron, P. (1998). Additional tests for a unit root allowing for a break in the trend function at an unknown time. International Economic Review, 39(4), 1073-1100. https://doi.org/10.2307/2527353

Wolf, H. (2005). Volatility: definitions and consequences. In J. Aizenman, \& B. Pinto (Eds.). Managing economic volatility and crises (pp. 45-64). United States: Cambridge University Press.

Zivot, E., \& Andrews, D. W. K. (1992). Further evidence on the Great Crash, the oil price shock and the unit root hypothesis. Journal of Business and Economic Statistics, 10(3), 251-279. Retrieved from https://www.jstor.org/stable/1391541, doi: 10.2307/1391541

\section{Notes}

Note 1. Ang (2010) examined the impact of GDP uncertainty on private investments of which he estimated the coefficient to be a small negative, nonetheless significant. Guiramaraes and Unteroberdoerster (2006) found real exchange rate volatility to be statistically insignificant in influencing private investments.

Note 2. Ghura and Goodwin (2000) estimates the domestic credit to GDP ratio coefficient to be +0.035 to +0.277 ; this estimated coefficient is smaller than Servén's (1998) and TunWai and Wong's (1982) $(+0.050$ to +2.931 and +0.731 to +1.18 , respectively). This implies that the importance of financial system may have been offset by the development of capital markets and cross-border financing.

Note 3. Internal uncertainties may be associated with unsustainable macroeconomic policies, political instability and domestic market imperfections (Wolf, 2005).

Note 4. Aizenman and Pinto (2005) argue that volatilities of fiscal spending and inflation are primarily a reflection of uncertainty in policy choices. In this regard, Aizenman and Marion (1993) include inflation uncertainty as a component of macroeconomic uncertainty which is found to have a negative impact on GDP growth.

Note 5. Servén (1998) finds in his principal component model that the RER plays an important role in summarising the combined volatility of five key macro variables namely GDP, inflation, t-o-t, the relative price of capital and RER.

Note 6. Servén (1998) also recognises the merits of using the GARCH method and have adopted this method to derive the measure of macro uncertainty in their studies.

Note 7. For variables that has monthly data series, ARCH/GARCH or ARMA model will use the monthly data will be used for the data generation process. The 12 months average is used to represent the yearly uncertainty that fits into the investment model.

Note 8. In order to find out if the ARCH effect is also present in the other times series data, we will have to go through the same steps described for CPI.

Note 9. While the negative correlations contradict expectations, the sign of the coefficient does not suggest 
causation. On the other hand, the negative correlation may suggest a smaller role of domestic financial institutions as there are increasing opportunities for firms to diversify their financing risks in the capital markets and engage in cross-border financing.

Note 10. However, Servén's (2003) found the impact of RER uncertainty to be significant for countries with low trade openness. Results appear to have contradicted the expectations that countries with higher degree of openness are more susceptible to RER uncertainty. Servén argued that countries with a higher degree of openness tend to have greater financial depth and therefore are less vulnerable to RER uncertainty. In general, most studies such as Byrne and Davis (2005a) and Darby et al. (1999) show that exchange rate volatility has a negative and significant impact on private investments. Byrne and Davis (2005a) estimated a 10\% increase in the level of exchange rate volatility relative to the average leads to a fall in investment of 1.0-1.5\% for G7 countries. However, Darby et al. (1999) argued that misalignments of exchange rate are just as important, where a 1\% increase in misalignment results in a fall of $0.9 \%$ to $2.3 \%$ in investments of five OECD countries.

\section{Copyrights}

Copyright for this article is retained by the author(s), with first publication rights granted to the journal.

This is an open-access article distributed under the terms and conditions of the Creative Commons Attribution license (http://creativecommons.org/licenses/by/4.0/). 